\title{
Pengaruh Pengungkapan Corporate Social Responsibility, Debt to Equity Ratio dan Profitabilitas terhadap Nilai Perusahaan Pada Perusahaan Manufaktur yang Terdaftar di Bursa Efek Indonesia
}

\author{
Ninta Katharina \\ Universitas Prima Indonesia \\ nintakatharina@unprimdn.ac.id
}

\begin{abstract}
Abstrak.
Tujuan dari penelitian ini adalah untuk menganalisis dan mengetahui pengaruh tanggung jawab sosial perusahaan, rasio hutang terhadap ekuitas dan kebijakan profitabilitas terhadap nilai perusahaan baik secara simultan maupun sebagian terhadap perusahaan manufaktur yang terdaftar di Bursa Efek Indonesia untuk periode 2016-2018. Populasi dalam penelitian ini adalah perusahaan yang terdaftar di Bursa Efek Indonesia. Dalam penelitian ini, peneliti menggunakan semua populasi untuk menjadi sampel penelitian (sensus) yaitu 30 perusahaan dengan rentang waktu selama 4 tahun berturut-turut sehingga total pengamatan adalah 90 . Penelitian ini menggunakan penelitian kuantitatif yang menekankan hubungan sebab akibat. Analisis data menggunakan model regresi berganda. Hasil tes ini membuktikan bahwa pengungkapan tanggung jawab sosial perusahaan, rasio hutang terhadap modal secara simultan dan profitabilitas berpengaruh secara bersama-sama terhadap nilai perusahaan. Pengungkapan sebagian tanggung jawab sosial perusahaan tidak memiliki pengaruh signifikan terhadap nilai perusahaan sedangkan rasio hutang terhadap modal dan profitabilitas memiliki pengaruh signifikan terhadap nilai perusahaan.
\end{abstract}

Kata kunci:Pengungkapan Tanggung Jawab Sosial Perusahaan, rasio hutang terhadap modal, Profitabilitas dan Nilai Perusahaan

\begin{abstract}
.
The purpose of this research is to analyze and to know the influence of corporate social responsibility, debt to equity ratio and profitability policy to the company value either simultaneously or partially to manufacturing company listed in Indonesia Stock Exchange for period 2016-2018. The population in this study is a company listed on the Indonesia Stock Exchange. In this study, the researcher used all the population to be a research sample (census) that is 30 companies with span of time for 4 consecutive years so total observation is 90 . This research uses quantitative research that emphasizes causal relations. Data analysis uses multiple regression models. The result of this test proves that simultaneously disclosure of corporate social responsibility, debt to equity ratio and profitability influence jointly on company value. Partially disclosure corporate social responsibility has no significant influence on corporate value while the debt to equity ratio and profitability have a significant influence on corporate value.
\end{abstract}

Keywords: Disclosure of Corporate Social Responsibility, debt to equity ratio, Profitability and Corporate Value

\section{PENDAHULUAN}

Nilai perusahaan yang tinggi akan diikuti oleh tingginya kemakmuran para pemegang saham. Nilai perusahaan merupakan acuan bagi para investor untuk menginvestasikan dana atau tidak yang diberikan dalam bentuk saham.
Meningkatnya nilai saham ditandai dengan tingkat pengembalian investasi yang tinggi kepada pemegang saham.(Febriana et al., 2016)

Manajemen disini berperan penting dan selalu berusaha untuk meningkatkan nilai perusahaannya, dikarenakan nilai perusahaan meningkat maka perusahaan 


\section{EKOMBIS Sains}

juga akan meningkatkan dan menguntungkan bagi para pemegang sahamnya dan mempermudah perusahaan mendapatkan pendanaan dari pihak investor. Pada saat ini banyak perusahaan memajukan demi meningkatkan nilai perusahaan. Namun kemajuan tersebut mengalami ketidakstabilan terutama pada ekosistem lingkungan seperti belakangan ini salah satu buktinya kondisi global warning.

Corporate social responsibility memberikan pemahaman bahwa perusahaan memiliki kemampuan dan rasa tanggung jawab terhadap pertumbuhan dan perkembangan lingkungan sekitar perusahaan tersebut beroperasi. Hal ini berarti bahwa perusahaan memberikan pelayanan jasa secara sukarela kepada masyarakat sehingga berdampak secara langsung terhadap nilai perusahaan di masyarakat.(Pattisahusiwa \& Diyanti, 2017)

Berdasarkan definisi tersebut dapat dilihat bahwa pentingnya kesadaran dalam pengungkapan corporate social responsibility oleh perusahaan. Tujuan dari adanya pengungkapan corporate social responsibility yaitu sebagai wujud tanggung jawab atau komitmen yang dilakukan oleh perusahaan atas dampak-dampak lingkungan yang ditimbulkan dari aktivitas bisnisnya

Konsep CSR pada umumnya menyatakan bahwa tanggung jawab perusahaan tidak hanya terhadap pemiliknya atau pemegang saham saja tetapi juga terhadap para stakeholder yang terkait dan/atau terkena dampak dari keberadaan perusahaan. Perusahaan yang menjalankan aktivitas CSR akan memperhatikan dampak operasional perusahaan terhadap kondisi sosial dan lingkungan dan berupaya agar dampaknya positif. Sehingga dengan adanya konsep CSR diharapkan kerusakan lingkungan yang terjadi di dunia, mulai dari penggundulan hutan, polusi udara dan air, hingga perubahan iklim dapat dikurangi (Awuy, 2016).

Pengungkapan Corporate Social Responsibility (CSR) merupakan suatu ide/gagasan dapat membuat perusahaan tidak hanya bertanggung jawab dalam hal keuangannya, melainkan terhadap sosial dan lingkungan sekitar perusahaan agar perusahaan dapat tumbuh secara berkelanjutan. Menurut Sari mengatakan tanggung jawab perusahaan tidak untuk wilayah perusahaan tetapi sampai pada kemasyaratan yang berada disekitar perusahaan.(Budiman, 2017)

Pengungkapan CSR timbul karena banyaknya masalah lingkungan yang terjadi akibat aktivitas operasional perusahaan. Dengan begitu menurut Undang-Undang No.40 Tahun 2007 tentang Perseroan Terbatas menyatakan bahwa perusahaan yang aktivitasnya terkait dengan sumber daya alam wajib mengungkapkan CSR.CSR bersifat mandatory dan voluntary, artinya CSR yang bersifat mandatory adalah perusahaan yang mengeluarkan limbah dan yang bersifat voluntary perusahaan yang tidak mengeluarkan limbah, tetapi termasuk dalam pengungkapan CSR.(Suparnyo et al., 2013)

$\begin{array}{crr}\text { Semakin } & \text { banyak } & \text { bentuk } \\ \text { pertanggungjawaban } & \text { yang } & \text { dilakukan }\end{array}$ perusahaan terhadap lingkungannya, maka image perusahaan menjadi meningkat. Investor lebih berminat pada perusahaan yang memiliki hutang yang sedikit dan citra yang baik di mata masyarakat karena semakin baiknya citra perusahaan, loyalitas konsumen semakin tinggi sehingga dalam waktu lama penjualan perusahaan akan membaik dan profitabilitas perusahaan juga meningkat.

Hutang merupakan salah satu pertimbangan bagi para investor dalam pengambilan keputusan investasi. Kebijakan ini termasuk kebijakan pendanaan perusahaan yang bersumber dari 


\section{EKOMBIS Sains}

eksternal. Banyak perusahaan menganggap penggunaan hutang dirasa lebih aman dari pada menerbitkan saham baru. Hutang bertambah terus menerus tanpa adanya pengontrolan dari pihak perusahaan hanya akan menimbulkan dampak negatif bagi nilai perusahaan artinya, investor akan ragu menanamkan sahamnya apabila perusahaan memiliki hutang yang ekstrem yang menimbulkan pertanyaan apakah perusahaan tersebut dapat dilunasi atau tidak.(Pradjnaparamitha, 2013)

Hal tersebut akan menurunkan reaksi negatif bagi para pemegang saham yang dapat mengakibatkan penjualan saham. Salah satu rasio yang digunakan yakni Debt to Equity Ratio (DER). Sebagian investor beranggapan DER meningkat akan berdampak buruk pada return. Selain itu, investor beranggapan jika semakin tinggi hutang, semakin beresiko suatu investasi. Sehingga banyak investor menghindari sebuah perusahaan dengan tingkat hutang yang tinggi. Seperti yang dikemukakan oleh Alfred bahwa "semakin kecil rasio DER, semakin baik kemampuan perusahaan untuk bertahan dalam kondisi yang buruk".

Profitabilitas juga salah satu bahan pertimbangan pihak investor dalam menanamkan sahamnya. Dimana profitabilitas tercermin pada harga saham dan ditunjukkan dalam kinerja keuangan pada bagaimana perusahaan menggunakan asset yang dimilikinya guna memperoleh laba maksimal. Profitabilitas diproksikan pada penelitian ini dengan return On Asset (ROA). ROA yang baik menunjukkan kinerja perusahaan yang baik, dengan demikian secara tidak langsung kinerja keuangan menunjukkan nilai perusahaan itu sendiri. Apabila kemampuan perusahaan untuk menghasilkan laba meningkat, maka harga saham juga akan meningkat.(Fasya, 2019)

Berdasarkan penelitian Hujaimatul Fauziah membuktikan bahwa Secara parsial program CSR PTPN VII, Lampung dalam hal ini adalah variabel permodalannya berpengaruh nyata dan positif terhadap peningkatan pendapatan usaha industri keripik di Bandar Lampung.(Fauziyah \& Fahrizi, 2019). Penelitian lainnya menunjukan bahwa Corporate social responsibility (CSR) berpengaruh positif terhadap Nilai perusahaan.(Fasya, 2019)

Fenomena yang terjadi pada nilai perusahaan dan hutang adalah jika kebijakan hutang meningkat maka akan meningkatnya nilai perusahaan, karena penggunaan hutang dapat menghemat pembayaran pajak, tetapi jika pengguna hutang yang terlalu tinggi dapat menurutkan nilai perusahaan. namun dengan meningkatkannya nilai perusahaan seharusnya profitabilitas perusahaan meningkat juga Tetapi Pada tahun 2015 terjadi penurunan profitabilitas disebabkan pengeluaran biaya perusahaan relatif tidak stabil, sehingga memberikan memberikan konstribuksi cukup besar terhadap biaya perusahaan.

Perusahaan cenderung memberikan informasi mengenai laba yang rendah sehingga perusahaan tersebut cenderung akan mengeluarkan biaya untuk pengungkapan informasi. Informasi akan diungkapkan oleh perusahaan apabila dapat mempengaruhi nilai perusahaan dan citra perusahaan. oleh sebab itu, pengungkapan CSR dapat digunakan sebagai keunggulan kompetitif perusahaan.

\section{KAJIAN LITERATUR}

\section{Nilai Perusahaan}

Nilai perusahaan pada dasarnya dapat diukur melalui beberapa aspek, salah satunya adalah dengan harga pasar saham perusahaan, karena harga pasar saham mencerminkan penilaian investor secara keseluruhan atas ekuitas perusahaan. Nilai perusahaan dapat memberikan kemakmuran kepada para pemegang saham apabila harga 


\section{EKOMBIS Sains}

saham meningkat. Semakin tinggi harga saham sebuah perusahaan, maka semakin tinggi pula kemakmuran para pemegang sahamnya.

\section{Pengungkapan CSR}

Pengungkapan (disclosure) sebagai penyajian sejumlah informasi yang dibutuhkan untuk pengoperasian secara optimal pasar modal yang efisien. Pengungkapan ada yang bersifat wajib (mandatory) dan ada yang bersifat sukarela (voluntary).

\section{Hutang (Debt to Equity Ratio / DER)}

DER merupakan rasio yang mengukur seberapa jauh perusahaan dibiayai oleh hutang, dimana semakin tinggi rasio ini menggambarkan gejala yang kurang baik bagi perusahaan. Peningkatan hutang pada gilirannya akan mempengaruhi besar kecilnya laba bersih yang tersedia bagi para pemegang saham termasuk dividen yang diterima karena kewajibannya untuk membayar hutang lebih diutamakan daripada pembagian dividen

\section{Profitabilitas}

Profitabilitas merupakan rasio yang digunakan untuk mengukur efektifitas manajemen yang dilihat dari laba yang dihasilkan terhadap penjualan dan investasi perusahaan. Investor di pasar modal sangat memperhatikan kemampuan perusahaan untuk menghasilkan, menunjang, dan meningkatkan profit. Profitability dapat diukur beberapa hal yang berbeda, namun dalam dimensi yang saling terkait

\section{Kerangka Konsep Dan Hipotesis}

Kerangka konsep pada penelitian disajikan sebagai berikut:

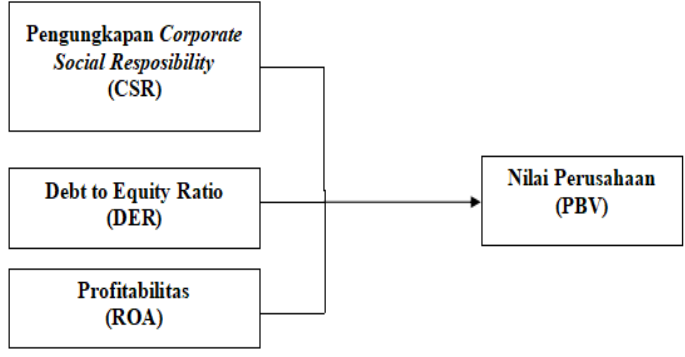

Gambar 1. Kerangka Konsep

\section{Hipotesis Penelitian}

Hipotesis penelitian ini adalah:

1. Pengungkapan CSR, iDER dan profitabilitas berpengaruh terhadap Nilai perusahaan secara simultan pada perusahaan yang terdaftar di Bursa Efek Indonesia.

2. Pengungkapan CSR, DER dan profitabilitas berpengaruh terhadap Nilai perusahaan secara parsial pada perusahaan yang terdaftar di Bursa Efek Indonesia.

\section{METODE PENELITIAN}

Sesuai dengan tujuan penelitian yaitu menguji hipostesis, maka penelitian ini termasuk penelitian kuantitatif yang menekankan pada hubungan kausal, yang menguji pengungkapan CSR, hutang dan profitabilitas sebagai variabel independen terhadap nilai perusahaan sebagai variabel dependen. Analisis data menggunakan model regresi berganda yang digunakan untuk mendetsi terpenuhi asumsi-asumsi.

\section{Populasi dan sampel}

Populasi tersebut maka peneliti menggunakan seluruh populasi menjadi data penelitian (sampel). Penelitian tersebut dinamakan sebagai penelitian sensus atau teknik sampling jenuh (lubis,2012). Penelitian ini melakukan pembatasan terlebih dahulu sebelum mengadakan teknik sampling jenuh. Jumlah sampel yang digunakan untuk penelitian ini berjumlah 30 perusahaan dengan 3 tahun pengamatan menjadi 90 data pengamatan 


\section{HASIL PENELITIAN DAN PEMBAHASAN}

\section{Hasil Analisis Data}

Sebelum melakukan pengujian hipotesis terlebih dahulu dilakukan pengujian asumsi klasik, pengujian ini dilakukan untuk mendeteksi terpenuhinya asumsi-asumsi dalam model regresi berganda dan untuk menginterpretasikan data agar lebih relevan dalam menganalisis. Pengujian asumsi klasik ini meliputi hasil uji normalitas yang bertujuan untuk mengetahui apakah dalam model regresi, variabel pengganggu atau residual memiliki distribusi normal (Ghozali, 2009). Dari hasil uji Kolmogorov-Smirnov Test nilai dari Asymp. Sig. (2-tailed) 0,183> $\alpha=0,05$ hal ini menunjukkan bahwa residual terdistribusi normal.

Uji multikolinearitas dilakukan untuk menguji apakah pada model regresi ditemukan adanya korelasi antar variabel independen. Model regresi yang baik adalah model regresi yang terbebas dari masalah multikolinearitas. Pengujian ada tidaknya gejala multikolinearitas dilakukan dengan melihat nilai VIF (Variance Inflation Factor) dan Tolerance. Nilai cutoff yang umum dipakai untuk menunjukkan adanya multikolinearitas adalah nilai toleransi $\leq$ 0,10 atau sama dengan nilai $\mathrm{VIF} \geq 10$ (Ghozali, 2009).

Hasil uji asumsi multikolinearitas menunjukkan bahwa tidak ada satupun variabel independen yang memiliki nilai VIF > 10 dan setiap variabel memiliki niali toleransi $>0,10$ sehingga disimpulkan bahwa model tidak mempunyai masalah multikolinearitas.

Uji heteroskedastisitas bertujuan menguji apakah dalam model regresi terjadi ketidaksamaan varians dari residual satu pengamatan ke pengamatan yang lain. Pada penelitian ini, peneliti menggunakan grafik Scatterplot. Hasil menunjukkan di dalam model tidak terjadi heteroskedastisitas karena dilihat bahwa titik-titik menyebar secara acak serta tersebar baik diatas maupun dibawah. Sehingga dapat disimpulkan bahwa model regresi ini layak dipakai dan tidak mengandung adanya heterokedastisitas.

Uji autokorelasi bertujuan menguji apakah dalam model regresi linear ada korelasi antara kesalahan penganggu pada periode $t$ dengan kesalahan penggangu pada periode $\mathrm{t}-1$ (sebelumnya).Pengujian autokorelasi menggunakan metode durbin Watson. Hasil menunjukkan bahwa tidak ada autokorelasi dalam model persamaan karena du $=1,006<\mathrm{DW}=1,512<4-\mathrm{du}=$ 2,579 .

\section{Pengujian Hipotesis dengan Uji F}

Pengujian hipotesis dilanjutkan dengan uji $\mathrm{F}$ untuk mengetahui pengaruh variabel independen secara simultan terhadap variabel dependen dengan tingkat signifikansi menggunakan alpha 5\% atau 0,05 dengan kriteria : (1) Jika F hitung $>\mathrm{F}$ Tabel, Maka Ho ditolak dan H1 diterima, (2) Jika F hitung < F tabel, maka Ho diterima dan $\mathrm{H} 1$ ditolak.

Tabel 1. Hasil Uji F

\begin{tabular}{|c|c|c|c|c|c|c|}
\hline \multicolumn{2}{|c|}{ Model } & $\begin{array}{c}\text { Sum of } \\
\text { Squares }\end{array}$ & $d f$ & Mean Square & $\mathrm{F}$ & Sig. \\
\hline \multirow[t]{3}{*}{1} & Regression & 39.694 & 3 & \multirow{3}{*}{$\begin{array}{r}13.231 \\
.776\end{array}$} & \multirow[t]{3}{*}{17.051} & \multirow[t]{3}{*}{$.000^{3}$} \\
\hline & Residual & 90.013 & 116 & & & \\
\hline & Total & 129.707 & 119 & & & \\
\hline
\end{tabular}

Dari uji $\mathrm{F}$ atau uji Anova diperoleh nilai $F$ hitung sebesar 17.051 dengan tingkat signifikansi sebesar $p=0,000$. Karena nilai probabilitas lebih kecil dari 0,05 dan Fhitung (17.051) > F tabel (2,37). Maka Ho ditolak, dan H1 diterima. Sehingga dapat ditarik kesimpulan bahwa variabel pengungkapan CSR, DER dan profitabilitas berpengaruh secara simultan terhadap nilai perusahaan, atau dapat dikatakan apabila CSR,DER dan ROA secara bersama-sama mengalami kenaikan atau penurunan maka 


\section{EKOMBIS Sains}

akan berdampak pada kenaikan atau penuruan nilai perusahaan.

\section{Pengujian Hipotesis dengan Uji t}

Pengujian hipotesis ini dilakukan untuk mengetahui secara parsial pengaruh CSR, DER dan ROA terhadap nilai perusahaan dengan menggunakan regresi berganda dan tingkat signifikansi alpha 5\% dengan kriteria:

1. Jika p-value $<0.05$, maka Ho ditolak atau H1 diterima

2. Jika p-value >0.05, maka Ho diterima dan $\mathrm{H} 1$ ditolak

Hasil pengujian hipotesis dengan uji $\mathrm{t}$ disajikan dalam tabel berikut ini:

\section{Tabel 2. Hasil Uji t}

\begin{tabular}{|c|c|c|c|c|c|c|}
\hline \multirow[b]{2}{*}{ Mode } & & \multicolumn{2}{|c|}{ Unstandardized Coefficients } & \multirow{2}{*}{$\begin{array}{c}\begin{array}{c}\text { Standardized } \\
\text { Coefficients }\end{array} \\
\text { Beta } \\
\end{array}$} & \multirow[b]{2}{*}{$t$} & \multirow[b]{2}{*}{ Sig. } \\
\hline & & $B$ & Std. Error & & & \\
\hline \multirow[t]{4}{*}{1} & (Constant) & .789 & .601 & & 1.313 & .192 \\
\hline & PCSR & -1.172 & .939 & -098 & -1.248 & .215 \\
\hline & ROA & .523 & .087 & .480 & 6.024 & .000 \\
\hline & DER & 237 & .117 & .159 & 2.021 & .046 \\
\hline
\end{tabular}

Berdasarkan hasil penelitian seperti pada tabel diatas, adapun persamaan regresi linier penelitian adalah sebagai berikut:

$$
\begin{gathered}
\mathrm{NP}=0,789-1,172 \mathrm{PCSR}+0,523 \mathrm{ROA} \\
+ \text { 0,237DER }+\mathrm{e}
\end{gathered}
$$

Berikut penjelasan mengenai model persamaan: Dilihat dari tabel diatas pengaruh variabel variabel PSCR, DER dan ROA secara parsial, maka hanya variabel PCSR tidak berpengaruh terdahap nilai perusahaan. Hal ini dibuktikan dengan signifikansi sebesar 0,215. Sedangkan pada variabel DER dan ROA dengan signifikansi 0,000 dan DER dengan signifikansi 0,046 < $\alpha=0,05$ menunjukkan angka yang lebih kecil, maka dapat disimpulkan variabel ROA dan DER mempunyai pengaruh signifikan terhadap nilai perusahaan.

\section{Interpretasi Ekonomi}

Corporate social responsibility memberikan pemahaman bahwa perusahaan memiliki kemampuan dan rasa tanggung jawab terhadap pertumbuhan dan perkembangan lingkungan sekitar perusahaan tersebut beroperasi. Hasil penelitian ini menunjukan secara mimulan Pengungkapan CSR, iDER dan profitabilitas berpengaruh terhadap Nilai perusahaan secara simultan pada perusahaan yang terdaftar di Bursa Efek Indonesia namun secara parsial pengungkapan CSR tidak mempunyai pengaruh signifikan terhadap nilai perusahaan pada perusahaan manufkatur yang terdaftar di Bursa Efek Indonesia periode 2016-2018. Dapat dilihat dari hasil penelitian menunjukan bahwa hasil uji korelasi adalah sebesar 0,877 yang menunjukkan adanya pengaruh positif kuat antara pendapatan usaha terhadap modal, volume pemasaran, volume teknologi, dan sumber daya manusia dari program kemitraan tersebut. Sedangkan jika hasil uji $R$ square menunjukkan sebesar 0,769 , ini berarti pengaruh variabel permodalan, sumberdaya manusia, manajemen pemasaran dan teknologi terhadap variabel pendapatan usaha secara keseluruhan adalah sebesar 76,9 persen dan sisanya yaitu sebesar 23,1 persen dipengaruhi oleh faktor-faktor lain misalnya factor regulasi, keamanan, dan lain-lain.(Fauziyah \& Fahrizi, 2019). Dengan demikian nilai perusahaan dipengaruhi Corporate Social Responsibility, Debt to Equity Ratio dan Profitabilitas

\section{KESIMPULAN DAN SARAN}

Berdasarkan hasil analisis dan pembahasan yang telah dilakukan, maka dapat disimpulkan sebagai berikut:

1. Secara simultan, bahwa pengungkapan CSR, profitabilitas dan hutang mempunyai pengaruh signifikan terhadap nilai perusahaan pada perusahaan manufkatur yang terdaftar di Bursa Efek Indonesia periode 2016-2018 


\section{EKOMBIS Sains}

2. Secara parsial, pengungkapan CSR tidak mempunyai pengaruh signifikan terhadap nilai perusahaan pada perusahaan manufkatur yang terdaftar di Bursa Efek Indonesia periode 2016-2018

3. Secara parsial, hutang mempunyai pengaruh signifikan terhadap nilai perusahaan pada perusahaan manufkatur yang terdaftar di Bursa Efek Indonesia periode 2016-2018

4. Secara parsial, profitabilitas mempunyai pengaruh signifikan terhadap nilai perusahaan pada perusahaan manufkatur yang terdaftar di Bursa Efek Indonesia periode 2016-2018

\section{Keterbatasan}

Beberapa keterbatasan dalam penelitian ini adalah sebagai berikut:

1. Pada kinerja keuangan yang digunakan hanya 2 variabel yakni DER dan ROA yang mempengaruhi nilai perusahaan.

2. Penelitian ini hanya meneliti lokasi penelitian pada perusahaan manufaktur yang terdaftar di Bursa Efek Indonesia.

\section{Saran}

Terkait temuan analisis penelitian diatas, dapatlah dikemukakan saran sebagai berikut:

1. Pada peneliti selanjutnya, perlu meneliti ulang dengan menambah atau mengurangi variabel-variabel lain dan menambah jumlah sampel pengamatan seperti salah satunya menambah tahun pengamatan.

2. Untuk selanjutnya, diharapkan pada pengukuran kinerja keuangan dapat menggunakan jenis-jenis rasio yang lebih banyak atau dapat menjadikan uji factor terlebih dahulu, sehingga indikator yang dipilih benar-benar dapat mewakili objek penelitian.

3. Pada peneliti selanjutnya, diharapkan menambah variabel moderasi sebagai variabel yang mempengaruhi hubungan antara variabel dependen terhadap independen (moderating) atau pengaruh langsung dan tidak langsung (intervening).

\section{DAFTAR PUSTAKA}

Awuy, V. P. Et Al.(2016). Pengaruh Pengungkapan Corporate Social Responsibility ( Csr ) Terhadap Earnings Response Coefficient ( Erc ) ( Suatu Studi Empiris Pada Perusahaan Pertambangan Yang Terdaftar Di Bursa Efek Indonesia Pada Tahun 2010-2013 ). Jurnal Akuntansi Dan Keuangan, 18(1), 15-26. Https://Doi.Org/10.9744/Jak.18.1.1526

Budiman, N. A. (2017). Faktor-Faktor Yang Mempengaruhi Pengungkapan Tanggung Jawab Sosial Perusahaan. 085228282256, 1(1). Https://Doi.Org/10.26486/Jramb.V1i1 .9

Fasya, A.(2019). Pengaruh Pengungkapan Corporate Social Responsibility Terhadap Nilai Perusahaan Dengan Profitabilitas Sebagai Variabel Moderasi. Jurnal Informasi Perpajakan, Akuntansi Dan Keuangan Publik, 13(2), 145-162.

Fauziyah, H., \& Fahrizi.(2019). Program Corporate Social Responsibility (Csr) Ptpn Vii, Lampung Sebagai Kegiatan Pemberdayaan Masyarakat Terhadap Upaya Meninmgkatkan Pendapatan Usaha Industri Keripik Di Kota Bandar Lampung. Ekombis Sains Jurnal Ekonomi Keuanga Dan Bisnis Universitas Sang Bumi Ruwa Jurai, 1689-1699.

Https://Doi.Org/10.1017/Cbo9781107 415324.004

Febriana, E., Djumahir, \& Djawahir, A. H. (2016). Kepemilikan Saham Manajerial Dan Profitabilitas 


\section{EKOMBIS Sains}

Terhadap Nilai Perusahaan (Studi Pada Perusahaan Manufaktur Yang Terdaftar Di Bei Pada 2011-2013). Jurnal Ekonomi Bisnis, 21(2), 163178.

Pattisahusiwa, S., \& Diyanti, F.(2017). Pengungkapan Corporate Social Responsibility, Struktur Corporate Governance Dan Nilai Perusahaan. Jurnal Ekonomi Modernisasi, 13(1), 25.

Https://Doi.Org/10.21067/Jem.V13i1. 1763

Pradjnaparamitha, O. (2013). Pengaruh Total Hutang Dan Perputaran Persediaan Terhadap Laba Bersih.
Journal Of Chemical Information And Modeling, 53(9), 1689-1699. Https://Doi.Org/10.1017/Cbo9781107 415324.004

Suparnyo, Wicaksono, A., \& Wiwit, A. (2013). Tanggung Jawab Sosial Perusahaan (Corporate Social Responsibility) Dan Implementasinya. Jurnal Sosial Dan Budaya, Vol 6, No. 